\title{
Synthesis and properties of two PRODAN-based fluorescent models of cholesterol
}

Christopher J. Abelt

College of William and Mary, cjabel@wm.edu

Follow this and additional works at: https://scholarworks.wm.edu/aspubs

Part of the Chemistry Commons

\section{Recommended Citation}

Abelt, Christopher J., Synthesis and properties of two PRODAN-based fluorescent models of cholesterol (2012). Journal of Photochemistry and Photobiology A - Chemistry, 238, 35-40.

10.1016/j.jphotochem.2012.04.011

This Article is brought to you for free and open access by the Arts and Sciences at W\&M ScholarWorks. It has been accepted for inclusion in Arts \& Sciences Articles by an authorized administrator of W\&M ScholarWorks. For more information, please contact scholarworks@wm.edu. 


\title{
Synthesis and Properties of Two PRODAN-based Fluorescent Models of Cholesterol
}

\author{
Nicholas A. Lopez and Christopher J. Abelt \\ Department of Chemistry, College of William and Mary, Williamsburg, VA 23187-8795
}

Christopher J. Abelt: cjabel@wm.edu

\begin{abstract}
The syntheses and photophysical properties of 1-(5-methylhexyl)-2,3,7,8-tetrahydro- $1 \mathrm{H}$ naphtho[2,1-e]indol-9(6H)-one (7a) and 1-(5-methylhexyl)-2,3,8,9-tetrahydro-1 $H$-naphtho[2,1e]indol-6(7H)-one (7b) are reported. They are prepared in eight steps from the corresponding bromonaphthylamines. These fluorescent compounds have PRODAN-like cores, and they are structurally similar to cholesterol. Compound 7a is the first reported PRODAN derivative where both the amino and carbonyl groups are constrained to be coplanar with the naphthalene core. Comparing the photophysical behavior of these compounds with related compounds indicates that locking the amino group in a five-membered ring enhances their desirable properties as solvent polarity sensors.
\end{abstract}

\section{Keywords}

PRODAN; fluorescent cholesterol model; solvatochromism

\section{Introduction}

Cholesterol is a singularly important biomolecule in animals. Its primary functions are to modify the structure and permeability of cell membranes and to serve as a precursor to a number of hormones. Determining the interaction between cholesterol and other biological structures is difficult because cholesterol is not readily detected. While it contains a single alkene, it is not amenable to analysis by electronic spectroscopy. One way to study the interaction between a non-fluorescent substrate like cholesterol with host systems is with suitable fluorescent model compounds. Several fluorescent cholesterol analogs have been prepared (Fig. 1). [1-3] These molecules fall into two extremes. Cholestatriene 1a and the related ergosterol derivative $\mathbf{1 b}$ conserve most of the structure of cholesterol, but the triene chromophore has a relatively low fluorescent quantum yield, and the absorption and emission maxima are bracketed between $300-400 \mathrm{~nm}$. The BODIPY and benzoxadiazol derivatives, $\mathbf{1 c}$ and $\mathbf{1 d}$, are on the other extreme. They add a significant structural perturbation to the cholesterol moiety, but the chromophores have high fluorescent quantum yields and they absorb and emit in the visible region (430-510 nm). However, the highly polar nature of the fluorophores strongly affects interactions with supramolecular structures

(C) 2012 Elsevier B.V. All rights reserved.

Correspondence to: Christopher J. Abelt, c jabel@wm. edu.

Publisher's Disclaimer: This is a PDF file of an unedited manuscript that has been accepted for publication. As a service to our customers we are providing this early version of the manuscript. The manuscript will undergo copyediting, typesetting, and review of the resulting proof before it is published in its final citable form. Please note that during the production process errors may be discovered which could affect the content, and all legal disclaimers that apply to the journal pertain. 
such as lipid bilayers. As a result, the suitability of these two derivatives as a cholesterol mimic has been questioned. $[1,4]$

PRODAN (6-propionyl-2-(dimethylamino)naphthalene, Fig. 2) is widely used as a fluorescent probe in the studies of biomolecules due to its optimal photophysical properties. It was first prepared 1979 by Weber and Farris who examined its interaction with bovine serum albumin (BSA).[5] Despite having a carbonyl group, the fluorescence quantum yield for PRODAN is nearly unity in polar solvents. The position of the fluorescence emission maximum shifts to progressively lower energy as the solvent polarity increases. This behavior is attributed to an increase in the molecular dipole moment of the excited state resulting from an intramolecular charge transfer (ICT). Twisting of the amino group has often been proposed to explain the solvatochromism (TICT hypothesis).[6-8] We have shown that PRODAN derivatives that enforce planarity of either the $3^{\circ}$ amino group $(\mathbf{2 b})$ or the carbonyl group (2d) behave like PRODAN, whereas the derivative with a twisted amino group (2c) behaves differently.[9-11] Derivatives where both groups are constrained to be planar have not been reported. The PRODAN regioisomer $2 \mathbf{e}$ and its constrained carbonyl derivative $\mathbf{2 f}$ are nearly as solvatochromic as PRODAN. Their quantum yields are slightly smaller, and they decrease markedly with increased solvent polarity.[12]

This paper reports the preparation and photophysical properties of two fluorescent cholesterol models that have a PRODAN-like fluorophore. While the structural perturbations are greater than in $\mathbf{1 a}$ and $\mathbf{1 b}$, they are not as extreme as they are in $\mathbf{1 c}$ and $\mathbf{1 d}$, and they preserve most of the desirable photophysical properties of $\mathbf{1 c}$ and $\mathbf{1 d}$.

\section{Experimental}

\subsection{General Methods}

NMR spectra are recorded on a Varian Mercury 400-Vx system. High resolution ESI-MS are acquired with a Bruker Apex-Qe instrument. Fluorescence emission data are collected using a SLM-Aminco SPF-500 spectrometer as the excitation source and sample holder. The emitted light is collected with a fiber optic cable and detected with an Ocean Optics Maya spectrometer. Solvents used for photophysical characterization are spectrophotometric grade from Acros. Relative fluorescence quantum yields in toluene are determined using anthracene $(\Phi=0.30)$ and 9,10-diphenylanthracene $(\Phi=0.90)$ as references using the method of standard additions. PM6/COSMO semiempirical calculations are performed using AMPAC 9.0 from Semichem, Inc (www.semichem.com). Calculations incorporate the following keywords: PM6; SDCI = 8; singlet; qcscf; cosmo; tight; truste; micros = 0; root = 1 (or 2); scfcrt $=0$. The values for dielec, iofr and rsolv are 2.3741, 1.4961 and 1, resp., for toluene and 35.688, 1.3442 and 1, resp., for acetonitrile.

\subsection{Materials}

Bromonaphthalenamines $\mathbf{3 a}$ and $\mathbf{3 b}$ are prepared through a Bucherer reaction from the corresponding bromonaphthols.[13,14]. 5-Methylhexyl methanesulfonate is made from 5methylhexan-1-ol and methanesulfonyl chloride and distilled under vacuum before use.

\subsection{Synthesis of Fluorescent Cholesterol Models and Intermediates}

2.3.1 N-(6-bromonaphthalen-2-yl)methanesulfonamide (4b)-Pyridine $(10 \mathrm{~mL})$ is added with stirring to a solution of 6-bromonaphthalen-2-amine (3b, $8.88 \mathrm{~g}, 40.0 \mathrm{~mol})$ in $\mathrm{CH}_{2} \mathrm{Cl}_{2}(100 \mathrm{~mL})$ cooled to $0{ }^{\circ} \mathrm{C}$. Next, a solution of methanesulfonyl chloride $(8.70 \mathrm{~g}, 75.9$ $\mathrm{mmol})$ in $\mathrm{CH}_{2} \mathrm{Cl}_{2}(10 \mathrm{~mL})$ is added dropwise. The mixture is stirred at $0{ }^{\circ} \mathrm{C}$ for $1 \mathrm{hr}$, then stirred at room temperature for $2 \mathrm{hr}$. The mixture is poured into aq. $\mathrm{NaHCO}_{3}(15 \mathrm{~g}, 300$ $\mathrm{mL}$ ), and the layers are stirred together rapidly for $30 \mathrm{~min}$. The solid that forms is collected 
by suction filtration. The two filtrate layers are separated, and the aqueous layer is extracted with $\mathrm{CH}_{2} \mathrm{Cl}_{2}(2 \times 50 \mathrm{~mL})$. The combined organic layers are washed with $10 \% \mathrm{HCl}(3 \times 50$ $\mathrm{mL}$ ), dried over $\mathrm{CaCl}_{2}$, filtered, and concentrated in vacuo. The slurry of the resulting solid in water is stirred rapidly and suction filtered. This solid is combined with the first solid and they are recrystallized from ethanol $(100 \mathrm{~mL})$ and water $(50 \mathrm{~mL})$ giving $\mathrm{N}$-(6-

bromonaphthalen-2-yl)methanesulfonamide $(7.87 \mathrm{~g}, 26.2 \mathrm{mmol}, 66 \%)$ after drying under vacuum at $100^{\circ} \mathrm{C}$, m.p. $169-170{ }^{\circ} \mathrm{C} .{ }^{1} \mathrm{H} \mathrm{NMR}\left(\mathrm{CDCl}_{3}\right) \delta 7.93(\mathrm{~s}, 1 \mathrm{H}), 7.71(\mathrm{~m}, 2 \mathrm{H}), 7.65(\mathrm{~d}$, $J=8.6 \mathrm{~Hz}, 1 \mathrm{H}), 7.52(\mathrm{~d}, J=8.1 \mathrm{~Hz}, 1 \mathrm{H}), 7.45(\mathrm{~d}, J=8.1 \mathrm{~Hz}, 1 \mathrm{H}), 3.00(\mathrm{~s}, 3 \mathrm{H}) ;{ }^{13} \mathrm{C} \mathrm{NMR}$ $\left(\mathrm{CDCl}_{3}\right) \delta 136.07,132.28,131.52,129.85,129.55,129.06,128.40,121.41,118.65,115.96$, 39.10. Found $[\mathrm{M}+\mathrm{Na}]^{+}$321.95097. $\mathrm{C}_{11} \mathrm{H}_{10} \mathrm{BrNO}_{2} \mathrm{SNa}^{+}$requires 321.95078 .

2.3.2 N-(5-Bromonaphthalen-2-yl)methanesulfonamide (4a)—This isomer (4.52 g, $15.1 \mathrm{~mol}, 81 \%)$ is made from 5-bromonaphthalen-2-amine (3a, $4.21 \mathrm{~g}, 18.7 \mathrm{mmol})$ using the procedure above, m.p. $164^{\circ} \mathrm{C}-165^{\circ} \mathrm{C} .{ }^{1} \mathrm{H} \mathrm{NMR}\left(\mathrm{CDCl}_{3}\right) \delta 9.67(\mathrm{~s}, 1 \mathrm{H}), 8.16(\mathrm{~d}, J=9.1 \mathrm{~Hz}$, $1 \mathrm{H}), 7.76(\mathrm{~s}, 1 \mathrm{H}), 7.75(\mathrm{~d}, J=8.0 \mathrm{~Hz}, 1 \mathrm{H}), 7.68(\mathrm{~d}, J=7.6 \mathrm{~Hz}, 1 \mathrm{H}), 7.54(\mathrm{~d}, J=9.1 \mathrm{~Hz}$, 1H)meta, $7.30(\mathrm{dd}, J=8.0,7.6 \mathrm{~Hz}, 1 \mathrm{H}), 3.01(\mathrm{~s}, 3 \mathrm{H}) ;{ }^{13} \mathrm{C} \mathrm{NMR}\left(\mathrm{CDCl}_{3}\right) \delta 136.83,135.31$, $129.14,129.06,128.79,127.61,127.18,122.61,121.69,116.07,39.32$. Found $[\mathrm{M}+\mathrm{Na}]^{+}$ 321.95096. $\mathrm{C}_{11} \mathrm{H}_{10} \mathrm{BrNO}_{2} \mathrm{SNa}^{+}$requires 321.95078 .

2.3.3 7-Bromo-3H-benzo[e]indole (5b)-Potassium carbonate $(2.35 \mathrm{~g}, 17.0 \mathrm{mmol})$ is added to a solution of $N$-(6-bromonaphthalen-2-yl)methanesulfonamide (4b, $7.87 \mathrm{~g}, 26.2$ $\mathrm{mmol}$ ) in DMF (25 mL) under Ar followed by 2-bromo-1,1-diethoxyethane $(9.4 \mathrm{~mL}, 62.5$ mol). The reaction mixture is heated overnight at $110^{\circ} \mathrm{C}$ with stirring. Another portion of 2bromo-1,1-diethoxyethane $(2.0 \mathrm{~mL}, 13.3 \mathrm{~mol})$ is added, and heating and stirring is continued overnight. When TLC analysis shows that the reaction is complete, the reaction is allowed to cool. The inorganic solids are removed by suction filtration, and the solid is washed with a small amount of $\mathrm{CH}_{2} \mathrm{Cl}_{2}$. The volatile solvent is removed in vacuo, and the higher boiling materials are removed by vacuum distillation $\left(0.1\right.$ Torr, up to $\left.145^{\circ} \mathrm{C}\right)$. The residue is taken up in $\mathrm{CH}_{2} \mathrm{Cl}_{2}(50 \mathrm{~mL})$, and boron trifluoride etherate $(4.0 \mathrm{~mL}, 31.6 \mathrm{mmol})$ is added. The reaction is stirred at room temperature overnight and monitored by TLC. The next day two more portions of boron trifluoride etherate $(1.0 \mathrm{~mL}$ ea, $15.8 \mathrm{mmol}$ total) are added, and the reaction is stirred at room temperature overnight. The following day the reaction mixture is poured slowly into aq. $\mathrm{NaHCO}_{3}(15 \mathrm{~g}, 200 \mathrm{~mL})$ with vigorous stirring. After the bubbling ceases, the mixture is diluted with $\mathrm{CH}_{2} \mathrm{Cl}_{2}(100 \mathrm{~mL})$, and the layers are separated. The aqueous layer is extracted with $\mathrm{CH}_{2} \mathrm{Cl}_{2}(2 \times 50 \mathrm{~mL})$. The combined organic layers are washed with $\mathrm{H}_{2} \mathrm{O}(200 \mathrm{~mL})$, dried over $\mathrm{CaCl}_{2}$, and concentrated in vacuo. A solution of $5 \%$ methanolic $\mathrm{KOH}(400 \mathrm{~mL})$ is added, and the reaction is heated at reflux overnight. The reaction is allowed to cool, and the contents are poured into $\mathrm{H}_{2} \mathrm{O}(600 \mathrm{~mL})$. The methanol is allowed to evaporate overnight. The resulting solid is collected by suction filtration, washed with water and air-dried. The filtrate is acidified with acetic acid $(50 \mathrm{~mL})$ and charged with $\mathrm{NaCl}(100 \mathrm{~g})$. The resulting solid is collected by suction filtration, washed with water, and air-dried giving unreacted $N$-(6-bromonaphthalen-2-yl)methanesulfonamide $(0.49 \mathrm{~g}, 1.6$ $\mathrm{mmol})$. The first solid is purified by vacuum sublimation $\left(0.1\right.$ Torr, $\left.\mathrm{T} \sim 200^{\circ} \mathrm{C}\right)$ giving 7 bromo-3H-benzo[e]indole $\left(3.20 \mathrm{~g}, 13.0 \mathrm{mmol}, 76 \%\right.$ over three steps), m.p. $122-124{ }^{\circ} \mathrm{C} .{ }^{1} \mathrm{H}$ $\operatorname{NMR}\left(\mathrm{CDCl}_{3}\right) \delta 8.11(\mathrm{~d}, J=8.6 \mathrm{~Hz}, 1 \mathrm{H}), 8.05(\mathrm{~d}, J=1.9 \mathrm{~Hz}, 1 \mathrm{H}), 7.61(\mathrm{dd}, J=8.6,1.9 \mathrm{~Hz}$, $1 \mathrm{H}), 7.56(\mathrm{~d}, J=9.0 \mathrm{~Hz}, 1 \mathrm{H}), 7.49(\mathrm{~d}, J=9.0 \mathrm{~Hz}, 1 \mathrm{H}), 7.31(\mathrm{~m}, 1 \mathrm{H}), 7.07(\mathrm{~m}, 1 \mathrm{H}) ;{ }^{13} \mathrm{C} \mathrm{NMR}$ $\left(\mathrm{CDCl}_{3}\right) \delta 132.38,130.68,128.97,126.84,125.00,122.91,122.84,122.12,116.94,114.00$, 102.09. Found $[\mathrm{M}-\mathrm{H}]^{-} 243.97656 . \mathrm{C}_{12} \mathrm{H}_{7} \mathrm{BrN}^{-}$requires 243.97674.

2.3.4 6-bromo-3H-benzo[e]indole (5a)_This isomer $(0.78 \mathrm{~g}, 3.17 \mathrm{mmol}, 40 \%$ overall conversion) is made from $\mathrm{N}$-(5-bromonaphthalen-2-yl)methanesulfonamide (4a, 2.50g, 8.33 mmol) using the procedure above, m.p. $93^{\circ} \mathrm{C}-96^{\circ} \mathrm{C} .{ }^{1} \mathrm{H} \mathrm{NMR}\left(\mathrm{CDCl}_{3}\right) \delta 8.50($ br s, $1 \mathrm{H})$, 
$8.21(\mathrm{~d}, J=7.7 \mathrm{~Hz}, 1 \mathrm{H}), 8.03(\mathrm{~d}, J=8.9 \mathrm{~Hz}, 1 \mathrm{H}), 7.71(\mathrm{~d}, J=7.4 \mathrm{~Hz}, 1 \mathrm{H}), 7.61(\mathrm{~d}, J=8.9 \mathrm{~Hz}$, $1 \mathrm{H}), 7.37(\mathrm{dd}, J=7.7,7.4 \mathrm{~Hz}, 1 \mathrm{H}), 7.31(\mathrm{~m}, 1 \mathrm{H}), 7.08(\mathrm{~m}, 1 \mathrm{H}) ;{ }^{13} \mathrm{C} \mathrm{NMR}\left(\mathrm{CDCl}_{3}\right) \delta 129.73$, $127.86,127.81,126.35,123.76,123.26,123.23,123.17,123.10,122.12,114.26,102.39$. Found $[\mathrm{M}-\mathrm{H}]^{-}$243.97657. $\mathrm{C}_{12} \mathrm{H}_{7} \mathrm{BrN}^{-}$requires 243.97674 .

2.3.5 7-bromo-3-(5-methylhexyl)-2,3-dihydro-1H-benzo[e]indole (6b)—Sodium hydride ( $250 \mathrm{mg}, 6.3 \mathrm{mmol}, 60 \%$ in oil, washed with hexanes) is added in one portion to a solution of 7-bromo- $3 H$-benzo[e]indole $(\mathbf{5 b}, 1.30 \mathrm{~g}, 5.28 \mathrm{mmol})$ in DMF $(25 \mathrm{~mL})$. After the reaction is complete, 5 -methylhexyl methanesulfonate $(1.00 \mathrm{~g}, 5.2 \mathrm{mmol})$ is added in one portion. The reaction is stirred under $\mathrm{N}_{2}$ overnight and monitored by TLC. The next day additional sodium hydride $(120 \mathrm{mg}, 3.0 \mathrm{mmol})$ is added followed in $10 \mathrm{~min}$ by 5 methylhexyl methanesulfonate $(0.40 \mathrm{~g}, 2.1 \mathrm{mmol})$. Stirring is continued overnight. The next day the reaction mixture is diluted with hexanes $(75 \mathrm{~mL})$ and $\mathrm{CH}_{2} \mathrm{Cl}_{2}(25 \mathrm{~mL})$. The organic layer is washed with water $(3 \times 100 \mathrm{~mL})$, then dried over $\mathrm{CaCl}_{2}$, and conc. in vacuo. The excess 5-methylhexyl methanesulfonate is removed by vacuum distillation ( 0.1 Torr, up to $\left.190^{\circ} \mathrm{C}\right)$ leaving 7-bromo-3-(5-methylhexyl)-3 $H$-benzo[e]indole $(1.63 \mathrm{~g})$ which is used without further purification. This solid is stirred vigorously with acetic acid $(40 \mathrm{~mL})$ while $\mathrm{NaCNBH}_{3}(3.30 \mathrm{~g}, 52.5 \mathrm{mmol})$ is added in several portions. The reaction is left to stir under $\mathrm{N}_{2}$ overnight. The contents of the reaction are poured slowly into aq. $\mathrm{NaHCO}_{3}(60 \mathrm{~g}, 500$ $\mathrm{mL}$ ), and the resulting mixture is stirred rapidly for $1 \mathrm{hr}$. The yellow precipitate that forms is collected by suction filtration and washed with water giving crude 7-bromo-3-(5-

methylhexyl)-2,3-dihydro-1H-benzo[e]indole (1.63 g, $4.71 \mathrm{mmol}, 89 \%)$ after air-drying. A portion was purified by vacuum sublimation for analysis, m.p. 50-51 ${ }^{\circ} \mathrm{C} .{ }^{1} \mathrm{H} \mathrm{NMR}\left(\mathrm{CDCl}_{3}\right)$ $\delta 7.85(\mathrm{~d}, J=1.6 \mathrm{~Hz}, 1 \mathrm{H}), 7.53(\mathrm{~d}, J=8.8 \mathrm{~Hz}, 1 \mathrm{H}), 7.41(\mathrm{dd}, J=8.9,1.6 \mathrm{~Hz}, 1 \mathrm{H}), 7.39(\mathrm{~d}, J=$ $8.9 \mathrm{~Hz}, 1 \mathrm{H}), 6.92(\mathrm{~d}, J=8.8 \mathrm{~Hz}, 1 \mathrm{H}), 3.52(\mathrm{t}, J=8.8 \mathrm{~Hz}, 2 \mathrm{H}), 3.22(\mathrm{t}, J=8.8 \mathrm{~Hz}, 2 \mathrm{H}), 3.14(\mathrm{t}$, $J=7.4 \mathrm{~Hz}, 2 \mathrm{H}), 1.60(\mathrm{~m}, 2 \mathrm{H}), 1.56(\mathrm{~m}, 2 \mathrm{H}), 1.40(\mathrm{~m}, 1 \mathrm{H}), 1.25(\mathrm{~m}, 2 \mathrm{H}), 0.89(\mathrm{~d}, J=6.6 \mathrm{~Hz}$, $6 \mathrm{H}) ;{ }^{13} \mathrm{C} \mathrm{NMR}\left(\mathrm{CDCl}_{3}\right) \delta 151.05,130.58,129.60,129.59,129.02,127.53,123.99,121.11$, $114.65,111.81,53.63,49.93,39.04,28.19,27.95,27.15,25.23,22.84$. Found $[\mathrm{M}]^{+}$ 345.10837. $\mathrm{C}_{19} \mathrm{H}_{24} \mathrm{BrN}^{+}$requires 345.10866.

2.3.6 6-Bromo-3-(5-methylhexyl)-2,3-dihydro-1H-benzo[e]indole (6a)-This isomer $(900 \mathrm{mg}, 2.60 \mathrm{mmol}, 86 \%)$ is made from 6-bromo-3H-benzo[e]indole $(\mathbf{5 a}, 0.78 \mathrm{~g}$, $3.17 \mathrm{mmol}$ ) using the procedure above, except that the final purification is by vacuum distillation. ${ }^{1} \mathrm{H}$ NMR $\left(\mathrm{CDCl}_{3}\right) \delta 8.04(\mathrm{~d}, J=9.0 \mathrm{~Hz}, 1 \mathrm{H}), 7.44(\mathrm{~d}, J=8.3 \mathrm{~Hz}, 1 \mathrm{H}), 7.42(\mathrm{~d}$, $J=7.6 \mathrm{~Hz}, 2 \mathrm{H}), 7.16(\mathrm{dd}, J=8.3,7.6 \mathrm{~Hz}, 1 \mathrm{H}), 6.95(\mathrm{~d}, J=9.0 \mathrm{~Hz}, 1 \mathrm{H}), 3.53(\mathrm{t}, J=8.8 \mathrm{~Hz}, 2 \mathrm{H})$, $3.21(\mathrm{t}, J=8.8 \mathrm{~Hz}, 2 \mathrm{H}), 3.15(\mathrm{t}, J=7.5 \mathrm{~Hz}, 2 \mathrm{H}), 1.58(\mathrm{~m}, 3 \mathrm{H}), 1.39(\mathrm{~m}, 2 \mathrm{H}), 1.24(\mathrm{~m}, 2 \mathrm{H})$, $0.90(\mathrm{~d}, J=6.7 \mathrm{~Hz}, 6 \mathrm{H}) ;{ }^{13} \mathrm{C} \mathrm{NMR}\left(\mathrm{CDCl}_{3}\right) \delta 151.46,132.32,127.92,126.74,126.21$, $125.46,123.93,122.21,121.38,111.87,53.72,49.76,39.09,28.24,27.93,27.35,25.27$, 22.91. Found $[\mathrm{M}]^{+}$345.10878. $\mathrm{C}_{19} \mathrm{H}_{24} \mathrm{BrNa}^{+}$requires 345.10866.

\subsubsection{1-(5-methylhexyl)-2,3,7,8-tetrahydro-1H-naphtho[2,1-e]indol-9(6H)-one}

(7b)-A solution of 7-bromo-3-(5-methylhexyl)-2,3-dihydro-1 $H$-benzo[e]indole ( $6 \mathbf{b}, 600$ $\mathrm{mg}, 1.73 \mathrm{mmol}$ ) in DMAC ( $8 \mathrm{~mL}$, freshly distilled from $\mathrm{CaH}_{2}$ ) under $\mathrm{N}_{2}$ is charged with $\mathrm{NiCl}_{2}\left(\mathrm{PPh}_{3}\right)_{2}(120 \mathrm{mg}, 0.18 \mathrm{mmol})$ and stirred for 15 minutes until the solution becomes homogeneous. A solution of 4-ethoxy-4-oxobutylzinc bromide $(5.0 \mathrm{~mL}, 0.5 \mathrm{M}$ solution in THF, $2.5 \mathrm{mmol}$ ) is added to the mixture. Stirring is continued for four hours. More $\mathrm{NiCl}_{2}\left(\mathrm{Ph}_{3}\right)_{2}(140 \mathrm{mg}, 0.21 \mathrm{mmol})$ is added. After 15 minutes of stirring, a solution of 4ethoxy-4-oxobutylzinc bromide $(3.0 \mathrm{~mL}, 1.5 \mathrm{mmol})$ is added. Stirring is continued overnight. The following day the mixture is poured into water $(200 \mathrm{~mL})$ and stirred for 1 hour. Salt is added to the mixture, and then the precipitated solid is collected with suction filtration. The solid is washed with water, air-dried and dried under vacuum overnight. The residue is covered with polyphosphoric acid $(\sim 5 \mathrm{~mL})$, heated to $110^{\circ} \mathrm{C}$ and stirred for two 
hours. The reaction is allowed to cool and then poured into aq. $\mathrm{NaHCO}_{3}(30 \mathrm{~g}, 300 \mathrm{~mL})$. The precipitated solid is collected with suction filtration and air-dried. The solid is purified through column chromatography using a gradient elution (hexanes, ethyl acetate). A final vacuum sublimation $\left(0.1\right.$ Torr, $\left.\mathrm{T} \sim 200^{\circ} \mathrm{C}\right)$ gave 1-(5-methylhexyl)-2,3,7,8-tetrahydro- $1 \mathrm{H}$ naphtho[2,1-e]indol-9(6H)-one (200 mg, $0.60 \mathrm{mmol}, 34 \%)$, m.p. $54-55^{\circ} \mathrm{C} .{ }^{1} \mathrm{H} \mathrm{NMR}$ $\left(\mathrm{CDCl}_{3}\right) \delta 9.22(\mathrm{~d}, J=9.3 \mathrm{~Hz}, 1 \mathrm{H}), 7.67(\mathrm{~d}, J=8.5 \mathrm{~Hz}, 1 \mathrm{H}), 7.22(\mathrm{~d}, J=8.5,1 \mathrm{H}), 7.02(\mathrm{~d}, J=$ $9.3 \mathrm{~Hz}, 1 \mathrm{H}), 3.50(\mathrm{t}, J=8.7 \mathrm{~Hz}, 2 \mathrm{H}), 3.24(\mathrm{t}, J=8.7 \mathrm{~Hz}, 2 \mathrm{H}), 3.15(\mathrm{t}, J=7.4 \mathrm{~Hz}, 2 \mathrm{H}), 3.04(\mathrm{t}$, $J=6.1 \mathrm{~Hz}, 2 \mathrm{H}), 2.75(\mathrm{t}, J=6.6 \mathrm{~Hz}, 2 \mathrm{H}), 2.15(\mathrm{tt}, J=6.6,6.1 \mathrm{~Hz}, 2 \mathrm{H}), 1.58(\mathrm{~m}, 3 \mathrm{H}), 1.40(\mathrm{~m}$, $2 \mathrm{H}), 1.24(\mathrm{~m}, 2 \mathrm{H}), 0.89(\mathrm{~d}, J=6.4 \mathrm{~Hz}, 6 \mathrm{H}) ;{ }^{13} \mathrm{C} \mathrm{NMR}\left(\mathrm{CDCl}_{3}\right) \delta 201.02,150.43,142.56$, 130.7, 128.76, 128.18, 127.51, 126.98, 124.92, 121.56, 113.01, 53.58, 50.05, 41.43, 39.08, $31.62,28.20,27.95,27.56,25.26,23.40,22.85$. Found $[\mathrm{M}+\mathrm{Na}]^{+} 358.21448 . \mathrm{C}_{23} \mathrm{H}_{29} \mathrm{NONa}^{+}$ requires 358.21414 .

\subsubsection{1-(5-methylhexyl)-2,3,8,9-tetrahydro-1H-naphtho[2,1-e]indol-6(7H)-one}

(7a)-This isomer (420 mg, $1.26 \mathrm{~mol}, 48 \%$ ) is made from 7-bromo-3-(5-methylhexyl)-2,3dihydro-1 $H$-benzo[e]indole $(6 \mathbf{6 a}, 900 \mathrm{mg}, 2.60 \mathrm{mmol})$ using the procedure above, m.p. 158$160^{\circ} \mathrm{C} .{ }^{1} \mathrm{H}$ NMR $\left(\mathrm{CDCl}_{3}\right) \delta 8.01(\mathrm{~d}, J=9.2 \mathrm{~Hz}, 1 \mathrm{H}), 7.93(\mathrm{~d}, J=9.2 \mathrm{~Hz}, 1 \mathrm{H}), 7.40(\mathrm{~d}, J=8.7$ $\mathrm{Hz}, 1 \mathrm{H}), 6.93(\mathrm{~d}, J=8.7 \mathrm{~Hz}, 1 \mathrm{H}), 3.61(\mathrm{t}, J=8.8 \mathrm{~Hz}, 2 \mathrm{H}), 3.27(\mathrm{~m}, 4 \mathrm{H}), 3.21(\mathrm{t}, J=7.3 \mathrm{~Hz}$, $2 \mathrm{H}), 2.68(\mathrm{t}, J=6.5 \mathrm{~Hz}, 2 \mathrm{H}), 2.24(\mathrm{t}, J=6.0 \mathrm{~Hz}, 2 \mathrm{H}), 1.62(\mathrm{~m}, 2 \mathrm{H}), 1.56(\mathrm{~m}, 1 \mathrm{H}), 1.39(\mathrm{~m}$, 2H), $1.25(\mathrm{~m}, 2 \mathrm{H}), 0.89(\mathrm{~d}, J=6.8, \mathrm{~Hz}, 6 \mathrm{H}) .{ }^{13} \mathrm{C} \mathrm{NMR}\left(\mathrm{CDCl}_{3}\right) \delta 198.4,152.81,144.54$, $133.37,126.42,126.08,124.58,123.64,121.77,121.04,110.33,53.26,48.99,39.03,38.49$, $28.19,27.89,27.05,26.15,25.20,23.12,22.82$. Found $[\mathrm{M}+\mathrm{Na}]^{+} 358.21425 . \mathrm{C}_{23} \mathrm{H}_{29} \mathrm{NONa}^{+}$ requires 358.21414 .

\section{Results and Discussion}

\subsection{Synthesis of fluorescent cholesterol models}

The reaction sequence for the preparation of $\mathbf{7 a}$ and $\mathbf{7 b}$ is shown in Scheme 1. Because the starting material is a naphthalene derivative, the synthesis results in the formation of a fivemembered ring containing the amine and a six-membered ring containing the carbonyl. The creation of the indole ring follows the procedure of Sundberg and Laurino.[15] Alkylation of the indole anion is exceptionally facile: it does not require heating and the anion is too weak a base to promote an elimination reaction with the mesylate. Reduction of the indole to the indoline must be carried out before subsequent generation of the carbonyl group. Creation of the cyclohexanone substructure is accomplished through a Negishi coupling followed by electrophilic cyclization directly from the ester. Prior hydrolysis of the ester is not necessary. For 7a substitution occurs at the only available ortho postion, whereas with $\mathbf{7 b}$ substitution occurs exclusively at the a-position of the naphthalene ring.

\subsection{Absorption and steady-state fluorescence studies}

The photophysical behavior of $\mathbf{7 a}$ and $\mathbf{7 b}$ in a range of aprotic solvents and two alcohols is reported in Table 1. The properties of related PRODAN derivatives are presented for comparison. In aprotic solvents fusing the amino group in a five-membered ring leads to a $\sim 14 \mathrm{~nm}$ bathochromic shift in the absorption for 7a vs. $2 \mathbf{d}$ and to a $\sim 24 \mathrm{~nm}$ shift in $\mathbf{7 b}$ vs. $2 \mathbf{f}$. The effects on the fluorescence are more striking. In $7 \mathbf{a}$ the emission maximum is shifted by $\sim 33 \mathrm{~nm}$. For $\mathbf{7 b}$ the average shift is by $84 \mathrm{~nm}$, but the magnitude increases from $58 \mathrm{~nm}$ to just over $100 \mathrm{~nm}$ as the solvent polarity increases. The effect of the fused ring is also seen in the relative fluorescence intensities. For 7a the intensity is relatively constant for all solvents. This behavior contrasts with that of PRODAN where the intensity drops precipitously in very nonpolar solvents. Relative fluorescence quantum yields for $7 \mathbf{a}$ are $0.70 \pm 0.05$ and $0.89 \pm 0.04$ in toluene and ethanol, respectively. For $7 \mathbf{b}$ the falloff in emission intensity with increasing solvent polarity is much more pronounced than in $\mathbf{2 f}$. The 
relative fluorescence quantum yields for $7 \mathbf{b}$ are $0.28 \pm 0.03$ in toluene and $0.016 \pm 0.004$ in ethanol. The effects of protic solvents on the emission maximum in $\mathbf{7 a}$ are similar to those with $2 \mathbf{a}$ and $\mathbf{2 d}$. The position of the maximum suffers an additional bathochromic shift due to hydrogen-bonding interactions. Alcohol solvents quench the fluorescence of $\mathbf{7 b}$. The peak maximum undergoes a slight hypsochromic shift in isopropanol, and a much larger shift in ethanol, indicating a different emitting species.

\subsection{Computational studies}

The electronic structures for the optimized ground and excited states of $\mathbf{7 a}$ and $\mathbf{7 b}$ are calculated using the PM6 semiempirical method with a conductor like screening model (COSMO) to account for solvent effects. For these calculations the long alkyl chain is treated as a methyl group $\left(\mathbf{7 a}^{\prime}\right.$ and $\left.\mathbf{7} \mathbf{b}^{\prime}\right)$, and configurational interaction is limited to singly and doubly excited microstates using eight orbitals bracketing the HOMO. This method and CI level were chosen because they best reproduce the absorption and fluorescence data shown in Table 2. For both chromophores the dipole moment doubles in the relaxed excited state. The ground and excited state dipole moments are not collinear: they form angles of $25^{\circ}$ and $70^{\circ}$ for $\mathbf{7} \mathbf{a}^{\prime}$ and $\mathbf{7 \mathbf { b } ^ { \prime }}$, respectively. The direction of the ground state dipole moments mostly derive from the carbonyl groups, whereas in the excited state the electron donation from the amino group becomes important. The change in the orientation of the ground and excited state dipole moments can be partially ascribed to the fixed positions of the carbonyl groups. The different angles for $\mathbf{7 a}^{\prime}$ and $\mathbf{7} \mathbf{b}^{\prime}$ result from the opposing directions of the carbonyl groups in addition to other electronic differences (e.g., direct resonance in $\mathbf{7 a}^{\prime}$ but not $\mathbf{7} \mathbf{b}^{\prime}$ ). As with PRODAN, $\mathbf{7 a}^{\prime}$ has two closelying Franck-Condon excited states within $0.2 \mathrm{eV}$, whereas in $\mathbf{7} \mathbf{b}^{\prime}$ the $S_{2}$ state is $>0.5 \mathrm{eV}$ higher in energy. For PRODAN, and by analogy $7 \mathbf{a}^{\prime}$, the consequence of these two states is an internal conversion to a chargetransfer state (ICT) with a different electronic configuration.[16][17] For $\mathbf{7} \mathbf{b}^{\prime}$ the relaxed excited state has the same electronic configuration (singly occupied HOMO and LUMO) as the ground state as is seen with $\mathbf{2 f}$.[12]

\subsection{Solvatochromic analysis}

Analysis of the solvatochromic data using various theoretical models allows for the determination of the excited state dipole moments for $\mathbf{7 a}$ and $\mathbf{7 b}$. In the Onsager model a combination of Lippert-Mataga (Fig. 3, Eq. 1) and Mataga plots (Fig. 4, Eq. 2) is typically sufficient to predict the ratio of the dipole moments of the excited and ground states $\left(\mu^{*} / \mu\right)$ without requiring the solute radius. However, this approach gives rise to very large values for the dipole moment ratios (5-10). Among the assumptions made in applying the Onsager model are a spherical fluorophore and collinear ground and excited dipole moments. Neither is accurate in the present case ( $c f$. Table 2 ). The requirement of a spherical shape is typically ignored. Eq. 3 (where $2 \pi \varepsilon_{0} \mathrm{hc}=1.105 \times 10^{-35} \mathrm{C}^{2}$ ) is used to calculate the excited state dipole moments when the collinearity condition is not satisfied. This expression only involves scalar terms. [18] Here the value of the Onsager radius is required, and a value of $5.1 \AA$ is calculated for $\mathbf{7 a}$ and $\mathbf{7 b}$ from the mass-density formula assuming a density of $0.95 \mathrm{~g}$ $\mathrm{mL}^{-1}$.[19] Only aprotic solvents are used in these analyses. As shown in Table 1, protic solvents give rise to unusual Stokes shifts because of the H-bonding interactions with the carbonyl group. The slopes of the best fit lines are greater in magnitude for $7 \mathbf{b}$ than for $\mathbf{7 a}$ in both the in the Lippert-Mataga $\left(m_{L-M}\right)$ plots $\left(5700 \mathrm{~cm}^{-1}\right.$ for $7 \mathbf{a}$ and $10400 \mathrm{~cm}^{-1}$ for $\left.7 \mathbf{b}\right)$ and for the Mataga $\left(m_{M}\right)$ plots $\left(-7300 \mathrm{~cm}^{-1}\right.$ and $-11200 \mathrm{~cm}^{-1}$, respectively). The dipole moments for the excited states derived from these plots are shown in Table 2. For 7a these values are slightly smaller than those predicted by the semiempirical calculations, whereas for $\mathbf{7 b}$ they are slightly larger. 


$$
\begin{gathered}
\tilde{v}_{a}-\tilde{v}_{e m}=\frac{\left(\mu^{*}-\mu\right)^{2}}{2 \pi \varepsilon_{0} h c a^{3}} \Delta f+\text { const. where } \Delta f=\frac{\varepsilon-1}{2 \varepsilon+1}-\frac{n^{2}-1}{2 n^{2}+1} \quad \text { Lippert-Mataga } \\
\tilde{v}_{e m}=\frac{\mu^{*}\left(\mu^{*}-\mu\right)}{2 \pi \varepsilon_{0} h c a^{3}} \Delta f^{\prime}+\text { const. where } \Delta f^{\prime}=\frac{\varepsilon-1}{2 \varepsilon+1}-\frac{1}{2} \bullet \frac{n^{2}-1}{2 n^{2}+1} \quad \text { Mataga } \\
\mu^{*}=\sqrt{\mu^{2}+\left(2\left|m_{M}\right|-m_{L-M}\right) 2 \pi \varepsilon_{0} h c a^{3}}
\end{gathered}
$$

Another empirical correlation for the determination of the excited state dipole moment has been developed by Ravi using Reichart's $E_{T}^{N}$ solvent parameter.[20,21] In this method the Stokes shift is plotted against $E_{T}^{N}$ as shown in Fig. 5. The slope of the best-fit line $\left(m_{R}\right)$ is related to the change in the dipole moments between the ground and excited states $\left(\Delta \mu=\mu^{*}\right.$ $-\mu)$ by Eq. 4. In this expression the subscript $B$ refers to the betaine dye used to develop the $E_{T}^{N}$ scale. For this pyridinium phenolate the Onsager radius $\left(a_{B}\right)$ is $6.2 \AA$, and the change in dipole moments $\left(\Delta \mu_{B}\right)$ is $9.0 \mathrm{D}$. The calculated excited state dipole moments from this analysis are shown in Table 2 . That the slope for $\mathbf{7 b}$ is greater than that for $\mathbf{7 a}$ indicates that the former undergoes a greater change in dipole moment upon excitation.

$$
\Delta \mu=\sqrt{\frac{m_{R}}{11308}\left(\frac{a}{a_{B}}\right)^{3}\left(\Delta \mu_{B}\right)^{2}}
$$

Insight into how solvent affects the photophysical behavior of these compounds can be made through multiparameter regression analysis with empirical solvent parameter scales. The recent generalized treatment of Catalán divides the effects into fours scales: polarizability (SP), dipolarity (SdP), acidity (SA) and basicity (SB).[22] In this analysis the Stokes shift is treated as a function of the solvent parameters by Eq. 5. The SA term is deliberately ignored because protic solvents are not included. A second analysis is reported for both compounds with fewer solvent parameters. Results for the regression analysis are shown in Table 3 . In general, the parameter fittings with $\mathbf{7 a}$ are not as good as with $\mathbf{7 b}$. Solvent basicity does not seem to play a significant factor in either compound. For $\mathbf{7 b}$ the Stokes shift appears to be primarily dependent on solvent dipolarity. This singular dependence on dipolarity was also reported with $\mathbf{2 f}$. [12] For 7a both dipolarity and polarizability are important.

$$
\tilde{v}_{a}-\tilde{v}_{e m}=c_{1} S P+c_{2} S d P+c_{3} S A+c_{4} S B+\tilde{v}_{0}
$$

\section{Conclusions}

Fluorescent cholesterol model compounds 7a and 7b have been prepared in eight steps from 6- and 5-bromo-2-naphthylamine. They show similar solvatochromic behavior as with simpler, structurally-related compounds $2 \mathbf{d}$ and $\mathbf{2 f}$. For $7 \mathbf{a}$ the effect of fusing the amino group into a five-membered ring decreases the fluorescence deactivation pathways especially in low polarity solvents. It must emit from a planar charge-transfer excited state. For $\mathbf{7 b}$ the ring fusion leads to progressively larger Stokes shifts with increasing solvent polarity. These greater shifts coincide with increased non-radiative decay that is characteristic of charge-transfer excited states. The absorption and emission profiles for 
these compounds make them potentially useful probes in biological systems as cholesterol models.

\section{Supplementary Material}

Refer to Web version on PubMed Central for supplementary material.

\section{Acknowledgments}

This research was supported by Grant 1R15 089925-01 from the NIH/NHLBI

\section{References}

1. Scheidt HA, Müller P, Herrmann A, Huster D. J Biol Chem. 2003; 278:45563. [PubMed: 12947110]

2. Li Z, Mintzer E, Bittman R. J Org Chem. 2006; 71:1718. [PubMed: 16468832]

3. Kao YJ, Soutar AK, Hong KY, Pownall HJ, Smith LC. Biochemistry. 1978; 17:2689. [PubMed: 678537]

4. Shaw JE, Epand RF, Epand RM, Li Z, Bittman R, Yip CM. Biophys J. 2006; 90:2170. [PubMed: 16361347]

5. Weber G, Farris FJ. Biochemistry. 1979; 18:3075. [PubMed: 465454]

6. Parusel A. J Chem Soc, Faraday Trans. 1998; 94:2923.

7. Parusel ABJ, Schneider FW, Köhler G. J Mol Struct: THEOCHEM. 1997; 398:341.

8. Parisio G, Marini A, Biancardi A, Ferrarini A, Mennucci B. J Phys Chem B. 2011; 115:9980. [PubMed: 21770447]

9. Davis BN, Abelt CJ. J Phys Chem A. 2005; 109:1295. [PubMed: 16833443]

10. Everett RK, Nguyen HAA, Abelt CJ. J Phys Chem A. 2010; 114:4946. [PubMed: 20329761]

11. Lobo BC, Abelt CJ. J Phys Chem A. 2003; 107:10938.

12. Abelt CJ, Sun T, Everett RK. Photochem Photobiol Sci. 2011

13. Sanguinet L, Twieg RJ, Wiggers G, Mao G, Singer KD, Petschek RG. Tetrahedron Lett. 2005; 46:5121.

14. Everett R, Hamilton J, Abelt C. Molbank. 2009:M602. [PubMed: 20556222]

15. Sundberg RJ, Laurino JP. J Org Chem. 1984; 49:249.

16. Zachariasse KA. Chem Phys Lett. 2000; 320:8.

17. Zachariasse KA, Druzhinin SI, Bosch W, Machinek R. J Am Chem Soc. 2004; 126:1705. [PubMed: 14871101]

18. Kawaki, A. Solvent-Shift Effect on Electronic Spectra and Excited-State Dipole Moments. In: Rabek, JF., editor. Progress in Photochemistry and Photophysics. Vol. 5. CRC; Boca Raton, FL: 1990. p. 1-47.

19. Roesch N, Zerner MC. J Phys Chem. 1994; 98:5817.

20. Ravi M, Soujanya T, Samanta A, Radhakrishnan T. J Chem Soc, Faraday Trans. 1995; 91:2739.

21. Reichardt, C.; Welton, T. Solvents and Solvent Effects in Organic Chemistry. Wiley-VCH Verlag $\mathrm{GmbH} ; 2011$.

22. Catalán J. J Phys Chem B. 2009; 113:5951. [PubMed: 19344103] 


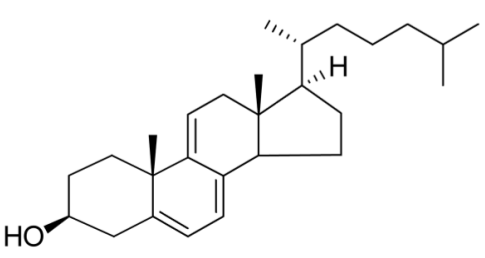

$1 \mathrm{a}$

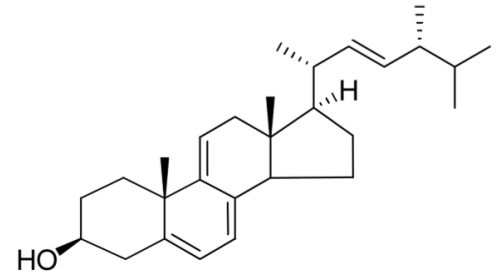

$1 b$

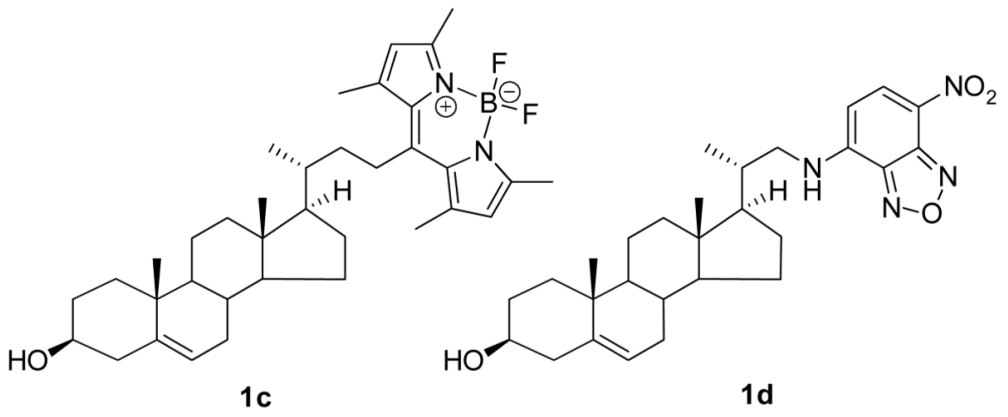

Figure 1.

Fluorescent cholesterol models 
<smiles></smiles><smiles>CCC(=O)c1ccc2c3c(ccc2c1)N(C)CCC3</smiles><smiles>CN(C)c1ccc2c3c(ccc2c1)C(=O)CCC3</smiles>

2d

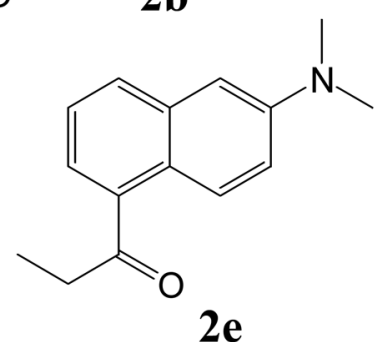<smiles>CCC(=O)c1ccc2cc3c(cc2c1)C1CCN3CC1</smiles>

Figure 2.

PRODAN (2a) and geometrically constrained derivatives (2b-d) and regioisomers (2e-f). 


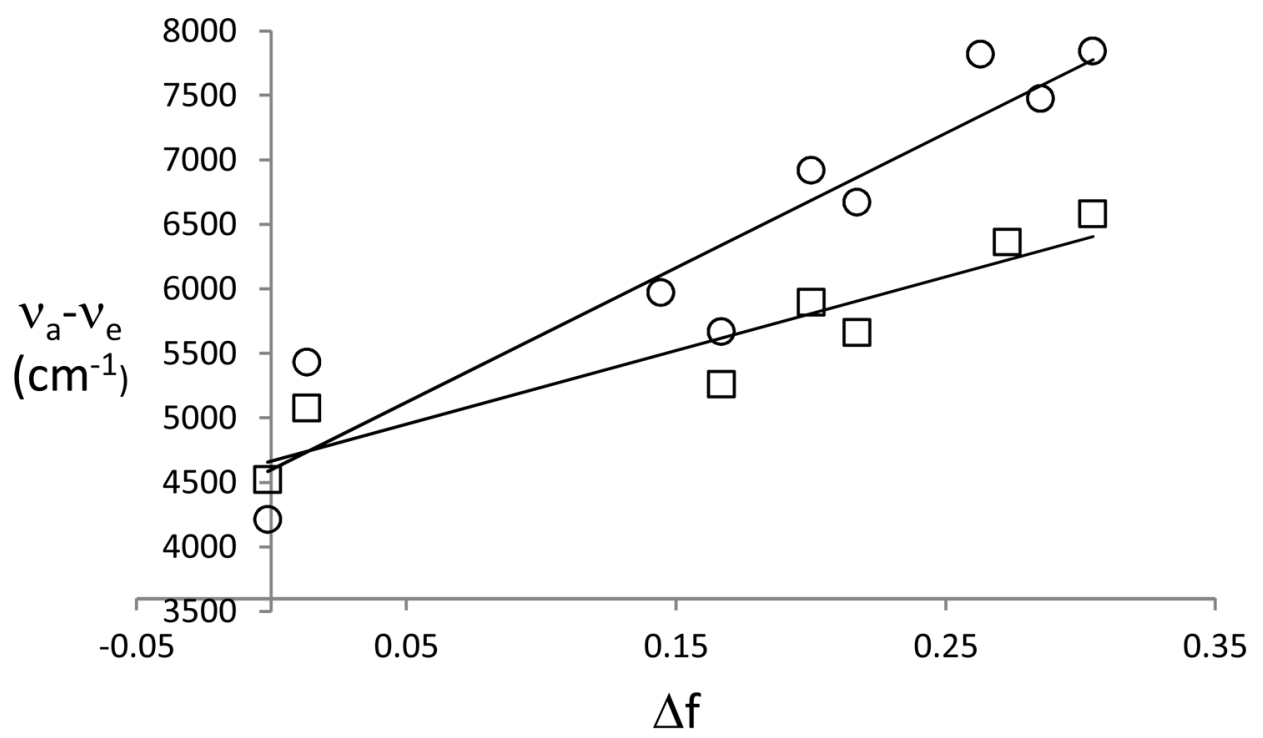

Figure 3.

Lippert-Mataga plots for $7 \mathrm{a}(\square)$ and $7 \mathrm{~b}(\bigcirc)$. 


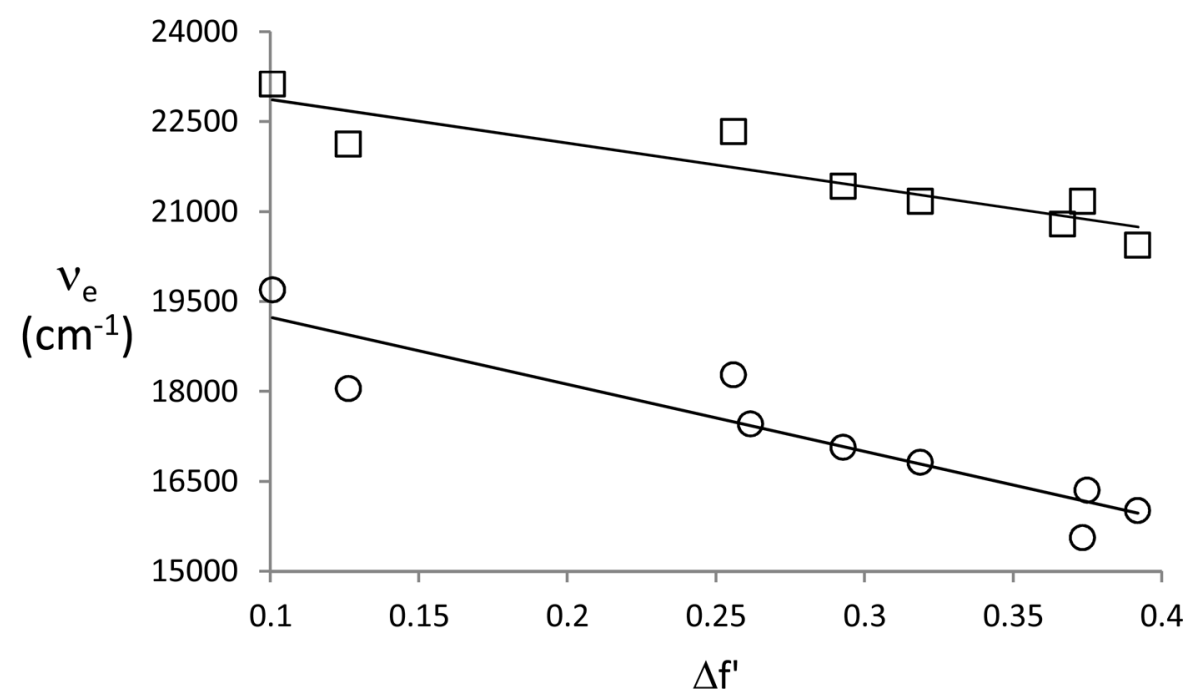

Figure 4.

Mataga plots for $7 \mathrm{a}(\square)$ and $7 \mathrm{~b}(\mathrm{O})$. 


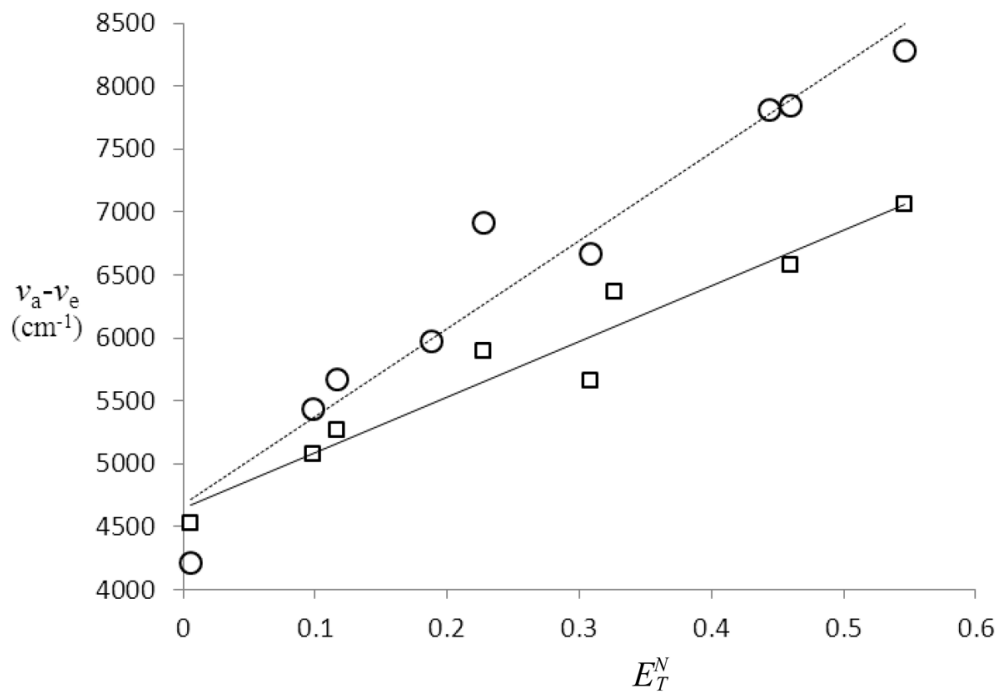

Figure 5.

Plot of Stokes shifts for $7 \mathrm{a}(\square)$ and $7 \mathrm{~b}(\bigcirc)$ vs. $E_{T}^{N}$ 
<smiles>Nc1ccc2c(Br)c(Cc3ccccc3)ccc2c1</smiles>

$3 a(3 b)$<smiles>Nc1ccc2c(Br)c(Cc3ccccc3)ccc2c1</smiles>

$4 a(4 b)$

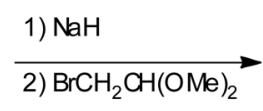

3) $\mathrm{PPA}, \triangle$

4) $\mathrm{NaOH}, \mathrm{MeOH}, \triangle$<smiles>O=C(c1ccccc1)c1ccc2c(ccc3[nH]ccc32)c1Br</smiles>

$5 a(5 b)$

$$
\text { 1) } \mathrm{NaH},\left(\mathrm{CH}_{3}\right)_{2} \mathrm{CH}\left(\mathrm{CH}_{2}\right)_{3} \mathrm{CH}_{2} \mathrm{OMs}
$$

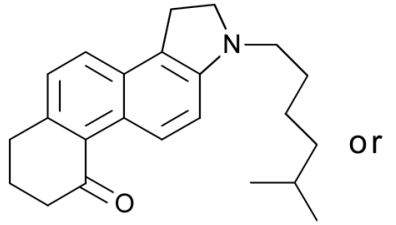

$7 b$

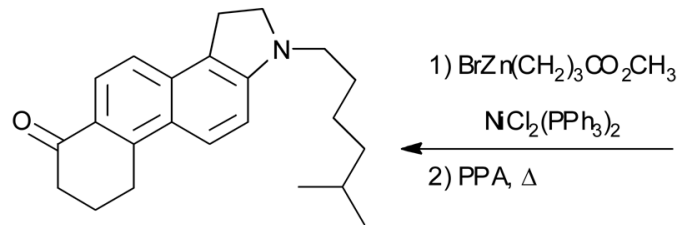

$7 a$<smiles>CC(C)CCCCN1CCc2c1ccc1c(Br)c(Cc3ccccc3)ccc21</smiles>

$6 a(6 b)$

Scheme 1.

Preparation of $7 a$ and $7 b$ 


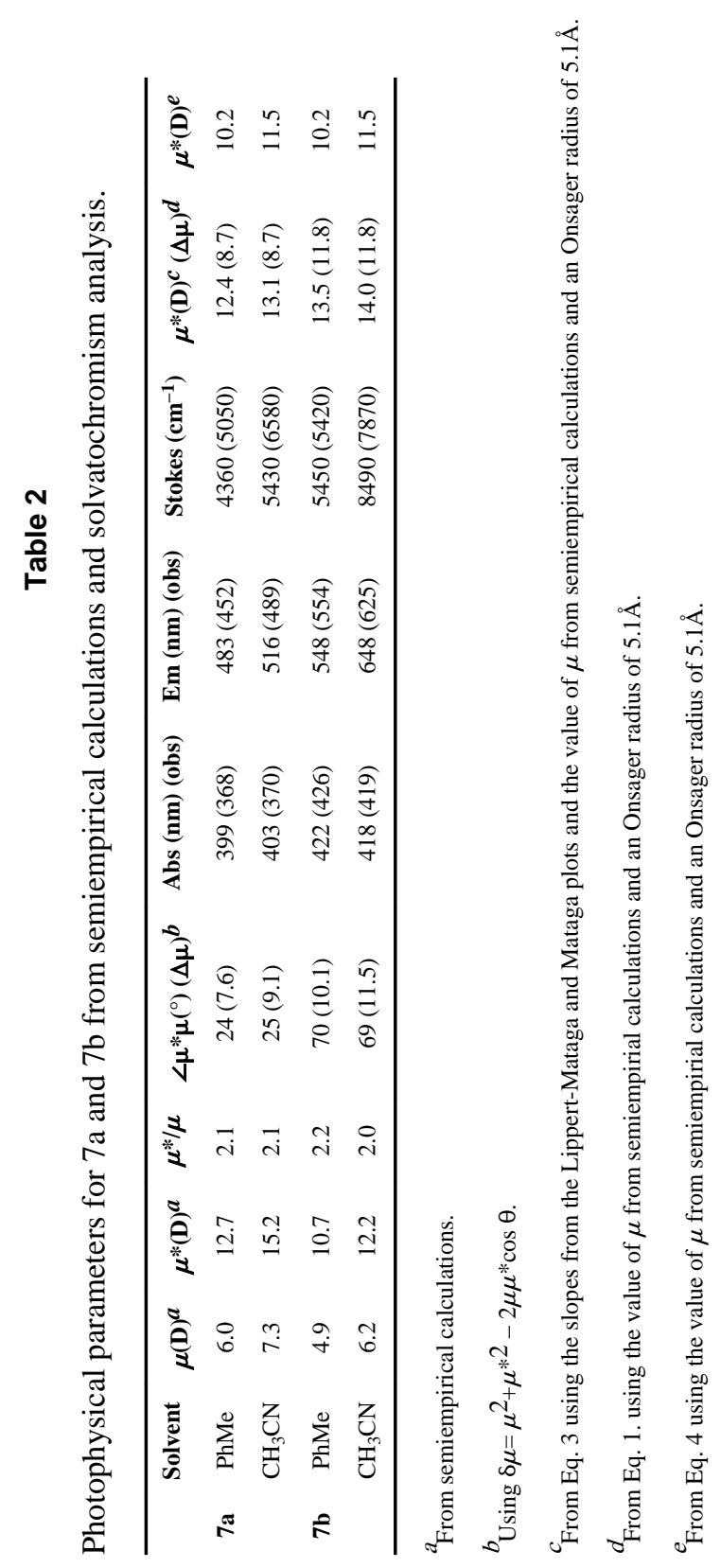




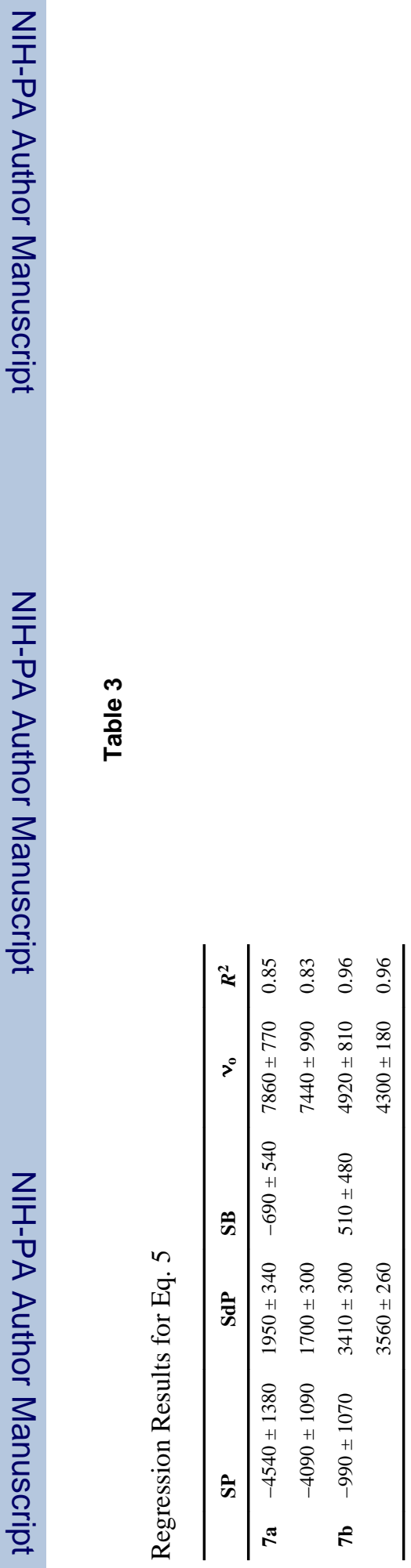

